\title{
Quantitative Chemobiology: A Guide into the Understanding of Plant Bioactivity
}

\author{
Otto R. Gottlieb* and Maria Renata de M. B. Borin \\ Instituto de Biologia Roberto Alcantara Gomes, Universidade do Estado do Rio de Janeiro (UERJ), \\ Rio de Janeiro, RJ, Brazil
}

\begin{abstract}
Hoje, nada é mais importante para a sobrevivência humana do que compreender os mecanismos da natureza através de uma linguagem químico-biológica. Essa abordagem multidisciplinar é uma complexa operação, pois envolve a integração de vários níveis de organização, tais como química, morfologia e ecogeografia, expressos respectivamente pela diversificação de metabolitos, formas e ambientes. A comparação entre essas diferentes expressões da vida, apesar de sua importância incontestável, ainda permanece um árduo tópico de pesquisa. Aplicação dessa abordagem unificada poderia revigorar o estudo de um assunto antigo e controvertido, a bioatividade vegetal. Enfrentar o maior desafio desse propósito: confrontar o conhecimento tradicional com uma metodologia científica, requer a determinação de tendências entre usos de espécies de angiospermas, independentemente de empirismos e regionalismos. Assim, incorporação de novos códigos, expressando funções biológicas, na linguagem químico-biológica é possível somente através de conceitos e padrões evolutivos.
\end{abstract}

Nothing is more important for human survival today, than understanding nature's mechanisms via a chemo-biological language. This multidisciplinary approach is a complex operation, because it involves integration of several levels of organization, such as chemistry, morphology and ecogeography, expressed by diversification of metabolites, forms and environments, respectively. A comparison among these different expressions of life, in spite of undisputed importance, still remains an arduous research topic. Application of this unified approach would revigorate the study of old and controversial matter, plant bioactivity. To face the major challenge toward this aim: confrontation of traditional knowledge with scientific methodology, required the determination of trends among the uses of angiosperm species independently of empiricisms and regionalities. Thus, incorporation of new codes, expressing biological functions, in the chemo-biological language becomes possible only through evolutionary concepts and patterns.

Keywords: ethnobotany, angiosperms, medicinal species, edible species, evolutionary patterns

\section{Introduction}

A considerable effort during several decades produced only modest knowledge on the chemical composition of the Brazilian flora. ${ }^{1}$ The fact is even less easy to understand, if it is considered that the value of medicinal products derived from tropical plants surpassed in recent times US\$ 6 billion per annum. ${ }^{2}$ Should it really be impossible to find ways and means to recover this enormous wealth in adequate time, or at least to design suitable process with such objectiveness? To face such problems is rather urgent. Already drug discovery is going down and disease resistance is going up. Today, more than 30,000 diseases

* e-mail: ogottlieb@abc.org.br

Present Address: Rua Cinco de Julho 323 apt. 1001, 22051-030 Rio de Janeiro - RJ, Brazil are clinically described. Less than one third of these can be treated symptomatically, and only a few can be cured. ${ }^{3}$ Meanwhile some pharmaceutical concerns continue to announce great expectations of "miraculous cures" based on medicinal plants. Others are looking for natural products of novel molecular skeletons from a variety of marine organisms. However, as yet, no compounds from the sea have advanced to commercial use as a chemotherapeutic agent. ${ }^{4}$ On the other hand, the quantitative structureactivity relationships (QSAR) approach has demonstrated great possibilities in drug-designs and drug-target interactions. Finally, synthetic, specifically projected, DNA-based wonder drugs are expected to alleviate human suffering in the future.

Thus, the first problem leads us to a second reasonable challenge: Is the study of medicinal plants really subject to scientific control? 
Brazil, the country of contrasts and paradoxes, is ideally suited to meet this biological challenge! The more than 8.5 million $\mathrm{km}^{2}$ shelter an enormous biological and cultural wealth. Besides big industrial populations there exist small native tribes that remain in their original state without any contact with the rest of the country, such as the Korubos tribe on the margins of Ituí river, Javari Valley, Amazonas, frontiers of Peru and Colombia. ${ }^{5}$ Out of 210 Brazilian indigenous populations, 55 live in similar social isolation since the time of colonization, 500 years before present.

And furthermore, should it also be possible to integrate traditional knowledge accumulated by generations in a scientific framework? If so, it should be possible not only to evaluate popular information scientifically, and also to predict bioactivity via a closer understanding of regulatory mechanisms of natural products. Without doubt, the first step in this endeavor is to assemble the available information for further analysis and rationalization. "At any rate, the role of science is not to establish some kind of factual data-bank about nature, but to help us understand nature". ${ }^{6}$

\section{Result and Discussion}

\section{Ethnobotany: Evolutionary patterns for useful plants}

Regional ethnobotanical inventories. In a first essay we introduced as database per regional ethnobotanical inventories of plants, utilized by three indigenous societies, living in different parts of Amazonia: Chácobo from Bolívia, ${ }^{7}$ Kayapó from Xingú ${ }^{8}$ and Ka'apor from Maranhão. ${ }^{9}$ The correlation among the frequency of useful plants (in percentages) per superorders (sensu Dahlgren ${ }^{10}$ ) with an evolutionary parameter based on herbaceousness indices (HI) reveals a common evolutionary trend: while more primitive plant species (lower HI) are used as foods, more recently evolved plant species (higher HI) are selected as medicines. ${ }^{11,12}$

The same conclusions arise when we analyze other inventories of useful plants, confirming the existence of general patterns. This discovery is surprising, if we consider that in this case non-human primates, represented by cebuella from Amazonia, ${ }^{13}$ spider monkey from Pará and Guyana $^{14}$ and muriqui from Atlantic forest, ${ }^{15,16}$ possess "knowledge" about useful plants similar to the human populations..$^{17}$ Thus, who learned what from whom?

Extensive ethnobotanical inventory. In a further attempt to confirm the universality of the previous results, we analyzed a vast ethnobotanical survey elaborated during the first years of the 20th century, chiefly in Brazil. ${ }^{18}$ To unify different databases, as the three regional indigenous surveys and this extensive Brazilian dictionary, it was necessary initially to develop an appropriate methodology. In short, the quantitative method for the determination of chemo-biological patterns implied the following stages: i) selection of dicotyledon species to which useful (edible and medicinal) properties had been assigned in these reports; ii) classification of these species at the level of families according to a system of classification (e.g. Dahlgren's system ${ }^{10}$ ); iii) characterization of each listed dicotyledon family by an ethnobotanical parameter (according to frequency of their useful species) and by an evolutionary parameter [according to Sporne indices $\left.(\mathrm{SI})^{19}\right] ; i v$ ) arrangement of these families according to their evolutionary status (i.e. by SI); v) Determination of the "evolutionary spectrum" for the ethnobotanical survey, considering the total frequency of useful species (in percentages) for each SI (cumulative frequencies).

This procedure allowed the characterization of each dicotyledon family by three types of information: systematic (according to Dahlgren's system ${ }^{10}$ ), evolutionary (according to Sporne indices, $\mathrm{SI}^{19}$ ) and ethnobotanical (according to percentage of useful species). Juxtaposing of these informations showed extraordinary consistencies. Frequently, the identical preferential (edible and/or medicinal) use of orders included in the same superorder was observed. This regularity of ethnobotanical indication was more common in medicinal orders of higher evolutionary status (Asteridae sensu Cronquist $^{20}$ ) than in edible orders of intermediate evolutionary status (Hamamelidade-Dilleniidae-Rosidae complex sensu Cronquist $\left.{ }^{20}\right) .{ }^{21}$ Practically the same trends of use for a vast survey ${ }^{18}$ and for three regionally and ethnically restricted Amazonian inventories (Chácobos, ${ }^{7}$ Kayapós ${ }^{8}$ and Ka' apors ${ }^{9}$ ) were observed. ${ }^{22}$

Other ethnobotanical inventories. Additionally to these four ethnobotanical surveys, eight inventories of different regions and continents were selected: three of food plants (one from Africa, ${ }^{23}$ one from North America ${ }^{24}$ and one from Brazilian Amazonia ${ }^{25}$ ); and five of medicinal plants (one from Africa, ${ }^{26}$ one from North America, ${ }^{27}$ two from Brazilian Amazonia, ${ }^{28,29}$ and one from Peruvian Amazonia ${ }^{30}$ ). Many features distinguish each one of these human groups, from the environmental point of view, as available resources, type of vegetation, climate and soil, to the sociocultural point of view, as management strategies, nutritional customs, inheritance of the traditional use of plants, illness characterizations and even mystic beliefs.

In order to compare these different databases, we selected in each inventory the dicotyledon groups, arranged according to their evolutionary status (SI), with more than 
$5 \%$ of the total food species (Table 1) and medicinal species (Table 2). This procedure allowed the elimination of the individual characteristics, i.e. the noises. While food species predominated in dicotyledon groups characterized by Sporne indices of 45, 48 and 57 (Table 1), medicinal species predominated in groups with Sporne indices of 37, 48, 57 and 72 (Table 2) in practically all inventories. Confirming the previous results, food species are limited by intermediate evolutionary status (SI $45-57$ ), only rarely attaining higher or lower SI values. Exceptions (SI 72) for Africa may indicate lack of foods; and for North America, where species utilized as beverage and other stimulants are considered additional food plants. In opposition, medicinal species occupy a large SI range (SI 37 - 72), often present at high evolutionary status (SI 72, 80). Thus, similar systematic and evolutionary patterns should be observed for all inventories analysed, independently of their dimensions and/or geographic localization. ${ }^{31}$

\section{Phytochemistry: Regulatory mechanisms of plant bioactivity}

The next, and very important, challenge consisted to look for chemical mechanism responsible for plant bioactivity. However, this task is very difficult, and until now without significative results, due to the many factors involved in the production, expression and regulation of natural products. An introspection in this subject, required

Table 1. Values of Sporne indices (SI) for groups of dicotyledon families with more than $5 \%$ of food species cited in different ethnobotanical inventories

\begin{tabular}{|c|c|c|c|c|c|c|c|c|c|c|c|c|c|c|c|c|c|c|}
\hline \multirow{2}{*}{$\begin{array}{l}\text { Ethnobotanical } \\
\text { Inventories }\end{array}$} & \multirow{2}{*}{$\begin{array}{l}\text { Total of } \\
\text { dicot. spp }\end{array}$} & \multicolumn{16}{|c|}{ SI of more important food dicotyledon groups ( $\mathrm{n}^{\circ}$. of food $\mathrm{spp}>5 \%$ ) } & \multirow{2}{*}{$\begin{array}{r}\text { Ranges } \\
\text { of SIs }\end{array}$} \\
\hline & & 35 & 40 & 42 & 43 & 45 & 48 & 50 & 51 & 52 & 53 & 54 & 55 & 57 & 60 & 62 & 72 & \\
\hline Africa $^{23}$ & 1,538 & & & $X$ & & $\mathrm{X}$ & $\mathrm{X}$ & & & $\mathrm{X}$ & & & & & & $\mathrm{X}$ & $\mathrm{X}$ & $42-72$ \\
\hline North America ${ }^{24}$ & 841 & & & & $\mathrm{X}$ & $\mathrm{X}$ & $\mathrm{X}$ & $\mathrm{X}$ & & $\mathrm{X}$ & $\mathrm{X}$ & & & $\mathrm{X}$ & $\mathrm{X}$ & & $\mathrm{X}$ & $43-72$ \\
\hline Brazil $^{18}$ & 458 & & & & $\mathrm{X}$ & $\mathrm{X}$ & $\mathrm{X}$ & & & & & & & $X$ & & & & $43-57$ \\
\hline Brazil-Amazonia $^{25}$ & 137 & & $\mathrm{X}$ & $\mathrm{X}$ & & $\mathrm{X}$ & $\mathrm{X}$ & $\mathrm{X}$ & & $\mathrm{X}$ & & & & $\mathrm{X}$ & & & & $40-57$ \\
\hline Chácobo $^{7}$ & 59 & & & & & $X$ & $X$ & $X$ & & & & & & $X$ & & & & $45-57$ \\
\hline Kayapó $^{8}$ & 12 & $\mathrm{X}$ & & & & $\mathrm{X}$ & $\mathrm{X}$ & & $\mathrm{X}$ & & & & $\mathrm{X}$ & $X$ & & & & $35-57$ \\
\hline $\mathrm{Ka}^{\prime}$ apor ${ }^{9}$ & 38 & & $X$ & & & $X$ & $X$ & $X$ & & $X$ & & $X$ & & $X$ & $X$ & & & $40-60$ \\
\hline
\end{tabular}

Table 2. Values of Sporne indices (SI) for groups of dicotyledon families with more than $5 \%$ of medicine species cited in different ethnobotanical inventories.

\begin{tabular}{|c|c|c|c|c|c|c|c|c|c|c|c|c|c|c|c|c|c|c|}
\hline \multirow{2}{*}{$\begin{array}{l}\text { Ethnobotanical } \\
\text { Inventories }\end{array}$} & \multirow{2}{*}{$\begin{array}{l}\text { Total of } \\
\text { dicot. spp }\end{array}$} & \multicolumn{16}{|c|}{ SI of more important medicinal dicotyledon groups $(\mathrm{n} \stackrel{\mathrm{o}}{ }$. of medicine $\mathrm{spp}>5 \%)$} & \multirow{2}{*}{$\begin{array}{l}\text { Ranges } \\
\text { of SIs }\end{array}$} \\
\hline & & 37 & 42 & 43 & 45 & 47 & 48 & 50 & 52 & 53 & 57 & 60 & 62 & 67 & 68 & 72 & 80 & \\
\hline Africa $^{26}$ & 924 & $\mathrm{X}$ & & & $\mathrm{X}$ & $\mathrm{X}$ & $\mathrm{X}$ & & & & $\mathrm{X}$ & & & & & $\mathrm{X}$ & & $37-72$ \\
\hline North America ${ }^{27}$ & 2,050 & & & $\mathrm{X}$ & & & $\mathrm{X}$ & & $\mathrm{X}$ & $\mathrm{X}$ & $\mathrm{X}$ & $\mathrm{X}$ & & & & $X$ & & $43-72$ \\
\hline Brazil $^{18}$ & 841 & $\mathrm{X}$ & & & & & $\mathrm{X}$ & $\mathrm{X}$ & $\mathrm{X}$ & & $\mathrm{X}$ & $\mathrm{X}$ & & & & $\mathrm{X}$ & & $37-72$ \\
\hline Brazil-Amazonia $^{28}$ & 296 & & & & $\mathrm{X}$ & & $\mathrm{X}$ & $X$ & $\mathrm{X}$ & & $X$ & & & & & $\mathrm{X}$ & & $45-72$ \\
\hline Brazil-Amazonia $^{29}$ & 52 & $X$ & & & $\mathrm{X}$ & & $X$ & & & & & $\mathrm{X}$ & & $\mathrm{X}$ & & $\mathrm{X}$ & & $37-72$ \\
\hline Peru-Amazonia ${ }^{30}$ & 56 & $\mathrm{X}$ & & & $\mathrm{X}$ & $\mathrm{X}$ & $\mathrm{X}$ & $\mathrm{X}$ & $\mathrm{X}$ & & & $\mathrm{X}$ & & & $\mathrm{X}$ & & $\mathrm{X}$ & $37-80$ \\
\hline Chácobo $^{7}$ & 109 & $\mathrm{X}$ & & & & & $\mathrm{X}$ & & $\mathrm{X}$ & & $X$ & $\mathrm{X}$ & & & $\mathrm{X}$ & & $X$ & $37-80$ \\
\hline Kayapó $^{8}$ & 63 & $\mathrm{X}$ & $\mathrm{X}$ & & $\mathrm{X}$ & $\mathrm{X}$ & $\mathrm{X}$ & & & $\mathrm{X}$ & $\mathrm{X}$ & & & & & & $\mathrm{X}$ & $37-80$ \\
\hline Ka'apor' ${ }^{9}$ & 22 & $\mathrm{X}$ & & & $\mathrm{X}$ & & $\mathrm{X}$ & $X$ & $\mathrm{X}$ & & $X$ & & $\mathrm{X}$ & & & $\mathrm{X}$ & & $37-72$ \\
\hline
\end{tabular}


the application of the same methodology above described, to phytochemical data (represented by number of occurrences of natural compounds). This procedure allowed the determination of evolutionary chemical patterns comparable to the evolutionary ethnobotanical patterns obtained. The choice of phytochemical data was based on our previous results demonstrating the fundamental importance of gallic and caffeic acids as metabolic regulators. ${ }^{32-34}$

The "spectral" features of the gallic-model were similar to the "spectral" features of the ethnobotany-guided food plants. In contradistinction, the analogous features of the caffeic-model were similar to the features of the ethnobotany-guided medicine plants. Indeed, the maxima of food species for practically all inventories corresponding to families with SI $=45,48$ and 57 (Table 1) corresponded to the maxima for gallic acid. Analogously, the maximum at $\mathrm{SI}=72$ was relative to medicine plants (Table 2) and caffeic acids. ${ }^{31}$

\section{Conclusion}

Now we are apt to face the challenge question announced in the introduction: How should we proceed to integrate traditional knowledge and scientific endeavour into a single framework? Trends among the uses of angiosperm species must possess systematic and evolutionary relevance in order to promote ethnobotanical descriptions to valid quantitative evolutionary codes. Thus, incorporation of new codes, expressing biological functions, in the chemo-biological language becomes possible only through evolutionary concepts and patterns. Indeed, remember Dobzhansky: "Nothing in biology makes sense", and from our point of view not even integration of ethnobotany and science makes sense, "except in the light of evolution". ${ }^{35}$

Finally, the complementary nature of food and medicine species can be rationalized by the involvement of plant metabolic cycles regulated via gallate/caffeate feedback loops. ${ }^{31}$ Hopefully this contribution should help to clarify the chemical and pharmacological potentialities of this enormous wealth in adequate time. This original procedure reveals the flexibility and importance of a dynamic and holistic approach into a crucial matter, an introspection of nature's functioning.

"We are the generation for whom the only message for a tropical biologist is: Set aside your random research and devote your life to activities that will bring the world to understand that tropical nature is an integral part of human life. If our generation does not do it, it won't be there for the next." (D. H. Janzen, 1986)

\section{Acknowledgments}

Supported by a grant from Academia Brasileira de Ciências, Rio de Janeiro, and by fellowships from Conselho Nacional de Desenvolvimento Científico e Tecnológico, Brasília and Fundação Carlos Chagas Filho de Amparo à Pesquisa do Estado do Rio de Janeiro, Rio de Janeiro, Brazil.

\section{References}

1. Gottlieb, O. R.; Interciencia 1981, 6, 22.

2. Plotkin, M. J.; Tales of a Shaman's Apprentice. An Ethnobotanist Searches for New Medicines in the Amazon Rain Forest; Penguin Books: New York, 1994.

3. Grabley, S.; Thiericke, R.; Zeeck, A. In Drug Discovery from Nature; Grabley, S.; Thiericke, R., eds.; Desktop Editions in Chemistry, Springer-Verlag: Berlin., 2000, p. 124.

4. Newman, D. J.; Cragg, G. M.; Snader, K. M.; Nat. Prod. Rep. 2000, 17, 215.

5. Propato, V.; Stuckert, R.; IstoÉ 1999, Sept. 15, 1563, (http:// www.terra.com.br/istoe/politica/156327.htm).

6. Stewart, I.; Cohen, J.; Figments of Reality. The Evolution of The Curious Mind; Cambridge University Press: Cambridge, 1997.

7. Boom, B. M.; Advances in Economic Botany 1989, 7, 78.

8. Anderson, A. B.; Posey, D. A.; Advances in Economic Botany 1989, 7, 159.

9. Balée, W.; Gély, A.; Advances in Economic Botany 1989, 7, 129.

10. Dahlgren, R. M. T.; Bot. J. Linn. Soc. 1980, 80, 91.

11. Gottlieb, O. R.; Borin, M. R. de M. B.; Bosisio, B. M.; Biotropica 1995, 27, 401.

12. Gottlieb, O. R.; Borin, M. R. de M. B. In Virtual Activity, Real Pharmacology - Different Approaches to the Search for Bioactive Natural Compounds; Verotta, L., ed.; Research Signpost: Trivandrum, 1997, p. 123.

13. Soini, P. In Ecology and Behavior of Neotropical Primates; Mittermeier, R. A.; Rylands, A. B.; Coimbra-Filho, A. F.; Fonseca, G. A. B., eds.; World Wildlife Fund: Washington, D. C., 1988, 79 .

14. Roosmalen, M. G. van; Klein, L. L. In Ecology and Behavior of Neotropical Primates; Mittermeier, R. A.; Rylands, A. B.; Coimbra-Filho, A. F.; Fonseca, G. A. B., eds.; World Wildlife Fund: Washington, D. C., 1988, 455.

15. Nishimura, A; Fonseca, G. A. B.; Mittermeier, R. A.; Young, A. L.; Strier, K. B.; Valle, C. M. C. In Ecology and Behavior of Neotropical Primates; Mittermeier, R. A.; Rylands, A. B.; Coimbra-Filho, A. F.; Fonseca, G. A. B., eds.; World Wildlife Fund: Washington, D.C., 1988, 577.

16. Strier, K. B.; Am. J. Primatology 1991, 29, 113. 
17. Gottlieb, O. R.; Borin, M. R. de M. B.; Bosisio, B. M.; American J. Primatology 1996, 40, 189.

18. Pio Corrêa, M.; Dicionário das Plantas Úteis do Brasil e das Exóticas Cultivadas; Imprensa Nacional: Rio de Janeiro, 1984.

19. Sporne, K. R.; New Phytol. 1980, 85, 419.

20. Cronquist, A.; The Evolution and Classification of Flowering Plants; $2^{\text {nd }}$ ed.; The New York Botanical Garden: New York, 1988.

21. Gottlieb, O. R.; Borin, M. R. de M. B.; Brito, N. R. S. de; Pure Appl. Chem. 2001, 73, 583.

22. Gottlieb, O. R.; Borin, M. R. de M. B.; An. Acad. Bras. Cienc. 2002, 74, 135.

23. Peters, C. R.; O’Brien, E. M.; Drummond, R. B.; Edible Wild Plants of Sub-Saharan Africa; The Royal Botanic Gardens: Kew, UK, 1992.

24. Beckstrom-Sternberg, S. M.; Duke, J. A.; http://arsgenome.cornell.edu/cgi-bin/WebAce/webace? $\mathrm{db}=$ foodplantdb (Data version July 1994).

25. Cavalcante, P. B.; Frutas Comestíveis da Amazônia; $6^{\mathrm{a}}$ ed.; Museu Paraense Emílio Goeldi: Belém, 1996.

26. Iwu, M. M.; Handbook of African Medicinal Plants; CRC Press: Boca Raton, Florida, 1993.
27. Beckstrom-Sternberg, S. M.; Moerman, D. E.; Duke, J. A.; http://ars-genome.cornell.edu/cgi-bin/WebAce/ webace $? d b=$ mpnadb (Data version June 1995).

28. Matta, A. A. da; Flora Medica Braziliense; Secção de Obras da Imprensa Official: Manaus, 1913.

29. Stasi, L.C. di; Santos, E. M. G.; Santos, C. M. dos; Hiruma, C. A.; Plantas Medicinais na Amazônia; Editora UNESP: São Paulo, 1989.

30. Desmarchelier, C.; Schaus, F. W.; Sixty Medicinal Plants from the Peruvian Amazon - Ecology, Ethnomedicine and Bioactivity; Peru, Lima, 2000.

31. Gottlieb, O. R.; Borin, M. R. de M. B.; Brito, N. R. S. de; Phtytochemistry 2002, 60, 145.

32. Gottlieb, O. R.; Borin, M. R. de M. B.; Kaplan, M. A. C.; Phytochemistry 1995, 40, 99.

33. Gottlieb, O. R.; Borin, M. R. de M. B.; Phytochemistry 1998, 49,1 .

34. Gottlieb, O. R.; Borin, M. R. de M. B.; Mem. I. Oswaldo Cruz 2000, 95, 115

35. Dobzhansky, T.; Ayala, F. J.; Stebbins, G. L.; Valentine, J. W.; Evolution; Freeman and Co.: San Francisco, 1977.

Received: June 6, 2002

Published on the web: November 8, 2002 